\title{
Diurnal body temperature patterns in free-ranging populations of two southern African arid-zone nightjars
}

\author{
Ryan S. O’Connor
}

DST-NRF Centre of Excellence at the Percy FitzPatrick Institute, Department of Zoology and Entomology, University of Pretoria, Private Bag X20, Hatfield 0028, South Africa. Email:ryan.oconnor@zoology.up.ac.za.

R. Mark Brigham

Department of Biology, University of Regina, Regina, Saskatchewan S4S OA2, Canada. Email: Mark.Brigham@uregina.ca.

Andrew E. McKechnie

DST-NRF Centre of Excellence at the Percy FitzPatrick Institute, Department of Zoology and Entomology, University of Pretoria, Private Bag X20, Hatfield 0028, South Africa. Email:aemckechnie@zoology.up.ac.za. 


\begin{abstract}
Endotherms allocate large amounts of energy and water to the regulation of a precise body temperature $\left(T_{b}\right)$, but can potentially reduce thermoregulatory costs by allowing $T_{b}$ to deviate from normothermic levels. Many data on heterothermy at low air temperatures $\left(\mathrm{T}_{\mathrm{a}}\right.$ ) exist for caprimulgids, whereas data on thermoregulation at high $\mathrm{T}_{\mathrm{a}}$ are largely absent, despite members of this taxon frequently roosting and nesting in sites exposed to high operative temperatures. We investigated thermoregulation in free-ranging Rufouscheeked Nightjars (Caprimulgus rufigena) and Freckled Nightjars (Caprimulgus tristigma) in the southern African arid zone. Individuals of both species showed labile $\mathrm{T}_{\mathrm{b}}$ fluctuating around a single modal $\mathrm{T}_{\mathrm{b}}\left(\mathrm{T}_{\mathrm{b}-\mathrm{mod}}\right)$. Average $\mathrm{T}_{\mathrm{b} \text {-mod }}$ was $39.7{ }^{\circ} \mathrm{C}$ for Rufouscheeked Nightjars and $39.0{ }^{\circ} \mathrm{C}$ for Freckled Nightjars. In both species, diurnal $\mathrm{T}_{\mathrm{b}}$ increased with increasing $\mathrm{T}_{\mathrm{a}}$. At $\mathrm{T}_{\mathrm{a}} \geq 38^{\circ} \mathrm{C}$, Rufous-cheeked Nightjar mean $\mathrm{T}_{\mathrm{b}}$ increased to $42{ }^{\circ} \mathrm{C}$, equivalent to $2.3{ }^{\circ} \mathrm{C}$ above $\mathrm{T}_{\mathrm{b} \text {-mod. }}$ Under similar conditions, Freckled Nightjar $\mathrm{T}_{\mathrm{b}}$ was on average only $1.1^{\circ} \mathrm{C}$ above $\mathrm{T}_{\mathrm{b} \text {-mod, }}$, with a mean $\mathrm{T}_{\mathrm{b}}$ of $40.0^{\circ} \mathrm{C}$. Freckled Nightjars are one of the most heterothermic caprimulgids investigated to date, but our data suggest that during hot conditions this species maintains $T_{b}$ within a narrow range above $\mathrm{T}_{\mathrm{b} \text {-mod, }}$, possibly reflecting an evolutionary tradeoff between decreased thermal sensitivity to lower $T_{b}$ but increased sensitivity to high $T_{b}$. These findings reveal how general thermoregulatory patterns at similar $\mathrm{T}_{\mathrm{a}}$ can vary even among closely related species.
\end{abstract}




\section{Introduction}

The scarce and unpredictable water resources, high air temperatures $\left(T_{a}\right)$ and intense solar radiation typical of deserts make them among the most physiologically challenging environments occupied by any organisms (Bartholomew and Cade 1963). When operative temperature $\left(T_{e}\right.$; Bakken 1976, Robinson et al. 1976) exceeds body temperature $\left(T_{b}\right)$ animals rely on evaporative heat dissipation to defend a $T_{b}$ set-point and avoid lethal heat stress (Dawson 1982). Consequently, at high $\mathrm{T}_{\mathrm{e}}$, animals encounter a trade-off between hyperthermia avoidance by means of evaporative cooling versus dehydration avoidance by conserving body water (Chew 1961, Cade and Dybas 1962, Willoughby and Cade 1967). Mismatches between water supply and demand are exacerbated in birds because of their small body size and high mass-specific rates of metabolism and evaporative water loss (EWL; Bartholomew and Dawson 1953, Bartholomew and Cade 1963, Wolf 2000, McKechnie and Wolf 2010).

The maintenance of water balance in hot environments may be particularly challenging for nocturnal birds, on account of the absence of diurnal water intake through drinking or the ingestion of food (Willoughby and Cade 1967, Fisher et al. 1972). Nightjars (Caprimulgidae) frequently roost and/or tend nests all day in open sites where solar radiation is intense and $\mathrm{T}_{\mathrm{e}}$ regularly exceeds $\mathrm{T}_{\mathrm{b}}$ (e.g., Cowles and Dawson 1951, Dexter 1956, Weller 1958, Howell 1959, Steyn 1971, Swisher 1978, Grant 1982, Ingels et al. 1984). Grant (1982), for instance, measured a black bulb temperature of approximately $58^{\circ} \mathrm{C}$ at a Lesser Nighthawk (Chordeiles acutipennis) nest and observed the incubating adult gular fluttering continuously for nearly $8 \mathrm{hr}$. Nightjars, therefore, are 
a taxon that would seemingly experience strong selective pressure for physiological mechanisms that minimize EWL and avoid dehydration.

Once regarded as a non-adaptive constant (Scholander et al. 1950), endotherm $T_{b}$ is now known to be highly variable (e.g., Tieleman and Williams 1999, McKechnie and Lovegrove 2002, Boyles et al. 2013, Ruf and Geiser 2015) and is increasingly being interpreted in an adaptive framework, whereby natural selection has influenced the mean and variance of the phenotype (Angilletta et al. 2010, Boyles et al. 2011a). At high $\mathrm{T}_{\mathrm{a}}$, birds can conserve water through facultative increases in $T_{b}$ (i.e., hyperthermia; Weathers 1981, Dawson 1982, Tieleman and Williams 1999). However, the magnitude of hyperthermia should vary depending on the co-adaptation between thermoregulation and thermal sensitivity (Angilletta et al. 2006, Angilletta et al. 2010, Boyles et al. 2011a). Endotherms whose performance is thermally insensitive are predicted to thermoregulate imprecisely but still perform well over a wide range of $\mathrm{T}_{\mathrm{b}}$ (i.e., thermal generalists). Conversely, endotherms that are thermal specialists should display less variation in $T_{b}$ and perform optimally over a narrower range of $\mathrm{T}_{\mathrm{b}}$. These two categorizations are not dichotomous, but represent two ends of a thermal continuum (Angilletta et al. 2006). Thus, a species', or even an individual's, thermoregulatory strategy for coping with thermal heterogeneity will vary depending on its position along this thermal continuum.

To date, most research on adaptive thermoregulation in free-ranging nightjars has focused on facultative hypothermic responses to cool conditions, periods of low lunar illumination and/or food shortage (e.g., Brigham 1992, Fletcher et al. 2004, Lane et al. 2004a, McKechnie et al. 2007, Smit et al. 2011, Brigham et al. 2012). In contrast, our knowledge of thermoregulation in free-ranging caprimulgids at high $\mathrm{T}_{\mathrm{a}}$ is essentially non- 
existent, despite this taxon's frequent use of exposed nest and roost sites making it an ideal group for investigating adaptive thermoregulatory responses to hot conditions. Additionally, given their proclivity for expressing heterothermy, caprimulgids offer an intriguing opportunity to investigate whether $T_{b}$ lability can also extend to high $T_{b}$. Here, we investigated patterns of core $T_{b}$ in two free-ranging southern African nightjar species in hot, arid habitats. Our objectives were to address several questions regarding thermoregulation by free-ranging nightjars exposed to high $T_{a}: 1$ ) do nightjars express facultative hyperthermia, with increases in maximum and/or mean $\mathrm{T}_{\mathrm{b}}$ during hot conditions?, 2) do free-ranging nightjars display a similar degree of heterothermy on days with higher maximum $\mathrm{T}_{\mathrm{a}}$ compared to lower maximum $\mathrm{T}_{\mathrm{a}}$ ?, and 3) do nightjars display the bimodal circadian rhythm of $\mathrm{T}_{\mathrm{b}}$ typical of most birds?

\section{Materials and methods}

\section{Study species and sites}

We investigated thermoregulation in Rufous-cheeked Nightjars at Dronfield Nature

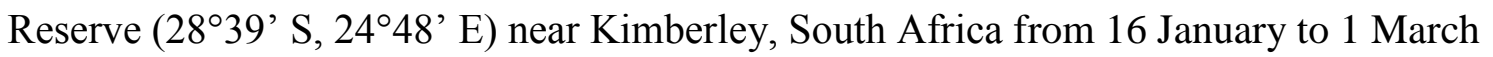
2014. Dronfield consists of arid savannah and camelthorn (Vachellia erioloba) woodland. Rainfall occurs mainly in summer, with $117 \mathrm{~mm}$ falling during our study period. Thermoregulation by Freckled Nightjars (Caprimulgus tristigma lentiginosus) was investigated between 5 December 2014 and 6 February 2015 on a privately owned farm in the Namaqualand region of the Northern Cape province, South Africa $\left(30^{\circ} 02^{\prime} \mathrm{S}\right.$, $17^{\circ} 57^{\prime}$ E). This study site is situated in the northern Kamiesberg Mountains and has previously been described by Boyles et al. (2012) and Smit et al. (2011). Rainfall in this 
region occurs predominantly in winter and only $2.6 \mathrm{~mm}$ fell during the study period. Weather data for each field site were recorded using a portable weather station (Vantage Pro2, Davis Instruments, Hayward, CA, USA), placed $~ 1.5-2 \mathrm{~m}$ above the ground. Air temperature was recorded every 5 min at Dronfield and every 15 min in Namaqualand.

Nightjars were captured at night either on roads with a handheld net and spotlight or by luring birds into mist-nets with conspecific call playback. After capture, nightjars were kept in a cage $(\sim 60 \times 71 \mathrm{~cm})$ constructed from PVC piping and shade cloth for 1-3 days. During this time, nightjars were also used for respiratory gas exchange measurements for the estimation of metabolic and EWL rates (O'Connor et al. 2017). While in captivity nightjars were hand-fed a diet of moist dog food, mealworms and water. On average, individuals lost $\sim 3 \%$ of their body mass $\left(\mathrm{M}_{\mathrm{b}}\right)$ following capture.

\section{Body temperature measurements}

Core $\mathrm{T}_{\mathrm{b}}$ was measured using two types of temperature-sensitive data loggers, namely Thermochron iButtons (model DS1922L, Maxim Integrated, San Jose, CA, USA; resolution $=0.0625^{\circ} \mathrm{C}$ ) for Freckled Nightjars and WeeDots (Alpha Mach Inc., Ste-Julie, Qc, Canada; resolution $=0.025^{\circ} \mathrm{C}$ ) for Rufous-cheeked Nightjars. Data loggers were calibrated in a water bath against a mercury thermometer with an accuracy traceable to the US National Bureau of Standards at temperatures between $5-50{ }^{\circ} \mathrm{C}$ in $5{ }^{\circ} \mathrm{C}$ increments (mean $\pm \mathrm{SD}$ iButton difference from thermometer $=0.4 \pm 0.4{ }^{\circ} \mathrm{C}$, WeeDot difference $\left.=-0.2 \pm 0.3^{\circ} \mathrm{C}\right)$. We programmed WeeDots to record $\mathrm{T}_{\mathrm{b}}$ every $5 \mathrm{~min}$ and iButtons every $15 \mathrm{~min}$. WeeDots come covered in a polyurethane coating to allow for submersion in wet environments. However, three metal contacts remain exposed for 
uploading data to a personal computer, and prior to implanting, these contacts were coated with a multi-purpose marine sealant (Sikaflex-291, Sika, Madison Heights, MI, USA) to prevent possible corrosion. iButtons were coated in a biologically inert surgical wax before implantation. Average WeeDot and iButton masses were $1.3 \pm 0.1 \mathrm{~g}$ and 3.3 \pm 0.2 g, respectively.

Nightjars were transported to a veterinary clinic where a registered veterinarian surgically implanted the temperature-sensitive data loggers intraperitoneally. Seven Rufous-cheeked Nightjars received WeeDots and 14 Freckled Nightjars were implanted with iButtons. On the morning of implantation, mean $\mathrm{M}_{\mathrm{b}}$ of Rufous-cheeked Nightjars was $53.8 \pm 4.2 \mathrm{~g}$ and $65.3 \pm 4.8 \mathrm{~g}$ for Freckled Nightjars. Both species were anesthetized with halothane (Safeline Pharmaceuticals [Pty] Ltd, Weltevredenpark, South Africa) via inhalation anesthesia. Nightjars were held in captivity for $3-12 \mathrm{hr}$ after surgery to ensure complete recovery. Often, individuals of both species were fully alert (e.g., standing on their own, "hissing/growling" and attempting to escape when held in the hand) within one hour following surgery. Nightjars were released at the site of capture at dusk on the same day of surgery. We attempted to recapture birds once we knew the data loggers had run out of memory. Recaptured nightjars were again transported to the veterinary clinic where the data loggers were extracted following the same procedure as for implantation. Nightjars were then released at the site of capture on the same day of data logger removal.

We also measured the core $\mathrm{T}_{\mathrm{b}}$ of a single incubating female Rufous-cheeked Nightjar from 26 October to 11 November 2015 at Dronfield. Incubating $\mathrm{T}_{\mathrm{b}}$ was measured using a passive-integrated transponder (PIT) tag (Biomark, Boise ID, USA) 
injected into the peritoneal cavity (Whitfield et al. 2015). Before the study, a subset of 70 PIT tags was calibrated in a circulating water bath against a thermocouple (type $\mathrm{T}$, Physitemp, Clifton, NJ, USA) at water temperatures from 39 to $46{ }^{\circ} \mathrm{C}$ (Whitfield et al. 2015). On average, PIT tags were within $0.02 \pm 0.09{ }^{\circ} \mathrm{C}$ of thermocouple values (Whitfield et al. 2015). The incubating adult was tracked to her nest based on a signal from a radio transmitter (BD-2T, Holohil Systems, Carp, Ontario, Canada) attached dorsally between the scapulars with a backpack-style harness constructed from Teflon ribbon (Telonics, Mesa, AZ, USA). Upon discovery of eggs on the ground, we buried a Biomark racket antenna under the eggs, allowing us to record $\mathrm{T}_{\mathrm{b}}$ only when the female was incubating. The racket antenna was connected to a 4-m long cable that was in turn connected to a portable transceiver system (model 2001F-ISO, Biomark, Boise, ID, USA). We powered the transceiver system using a $12 \mathrm{~V}, 7.5$ A battery. The transceiver was programmed to record $\mathrm{T}_{\mathrm{b}}$ every minute and we visited the site once each day to download the data to a personal computer and replace the battery. During these visits, the incubating bird rarely flushed and remained tight on the eggs.

\section{Data analyses}

All statistical analyses were conducted in R 3.2.4 (R Core Team 2016) with all values reported as mean \pm standard deviation (SD). Species mean values were calculated by taking an average across individual bird averages. When reporting individual bird means, we provide the number of observations used in the calculation (designated with a lowercase n). Data were separated into four distinct periods, namely daily (midnight to midnight), diurnal (sunrise to sunset), twilight (civil and nautical twilight combined) and 
nocturnal (end of dusk nautical twilight to start of dawn nautical twilight). The end of civil and nautical twilight are defined as when the sun is $6^{\circ}$ and $12^{\circ}$ below the horizon, respectively (Mills 2008). We used the end of nautical twilight as the start of the night because nightjars have been shown to reduce their activity at this point in the absence of lunar illumination (Mills 1986, Jetz et al. 2003). Sunrise and sunset times for each study site were determined using the function 'sunriset' in the R package maptools (Bivand and Lewin-Koh 2016). The end and start of nautical twilight for each study site was determined using SunCalc (http://www.suncalc.net/).

We used the nlme (Pinheiro et al. 2016) and lme4 (Bates et al. 2015) packages to fit linear mixed-effects models and perform three separate analyses on free-ranging diurnal $\mathrm{T}_{\mathrm{b}}$ data. First, we modelled variation in diurnal $\mathrm{T}_{\mathrm{b}}$ with $\mathrm{T}_{\mathrm{a}}$ as a predictor variable. Second, we modelled variation in maximum diurnal $\mathrm{T}_{\mathrm{b}}\left(\mathrm{T}_{\mathrm{b}-\mathrm{max}}\right)$ as a function of maximum diurnal $\mathrm{T}_{\mathrm{a}}\left(\mathrm{T}_{\mathrm{a}-\mathrm{max}}\right)$. Lastly, we modelled diurnal heterothermy with $\mathrm{T}_{\mathrm{a}-\mathrm{max}}$ as a predictor variable using a comparative metric known as the heterothermy index (HI; Boyles et al. 2011b):

$$
\mathrm{HI}=\sqrt{\frac{\sum\left(\mathrm{T}_{\mathrm{b}-\bmod }-\mathrm{T}_{\mathrm{b}-\mathrm{i}}\right)^{2}}{n-1}},
$$

where $\mathrm{T}_{\mathrm{b}-m o d}$ is the modal $\mathrm{T}_{\mathrm{b}}, \mathrm{T}_{\mathrm{b}-\mathrm{i}}$ is the measured $\mathrm{T}_{\mathrm{b}}$ at time $i$ and $n$ is the number of times $\mathrm{T}_{\mathrm{b}}$ is sampled. We follow Boyles et al. (2011b) and assume that $\mathrm{T}_{\mathrm{b}}$ is adaptive and the most frequently occurring $\mathrm{T}_{\mathrm{b}}$ should equal the optimal $\mathrm{T}_{\mathrm{b}}$. Thus, we use $\mathrm{T}_{\mathrm{b}-\mathrm{mod}}$ as $\mathrm{a}$ proxy of optimal $T_{b}$. We calculated a $T_{b-m o d}$ for each bird by pooling all $T_{b}$ values collected for each recording period. A species average $\mathrm{T}_{\mathrm{b}-\mathrm{mod}}$ represents the average of individual bird $\mathrm{T}_{\mathrm{b} \text {-mod. }}$ 
For all linear mixed-effects models we included bird identity as a random effect due to repeated measurements on the same individual. We assessed the goodness-of-fit of each model by graphically inspecting residuals for homogeneity and normality.

Frequently our models violated assumptions of homogeneity due to skewed distributions in our response variable and we subsequently either included a variance structure in our models (Zuur et al. 2009) or implemented a robust linear mixed-effects model using the R package robustlmm (Koller 2016). For each analysis, we report the effect size of the predictor variable on the response, represented as the parameter estimate $(\beta)$, and the accompanying standard error (SE) and $95 \%$ confidence interval $(95 \% \mathrm{CI})$. To further assess the magnitude of hyperthermia throughout the diurnal period, we calculated mean deviations in $\mathrm{T}_{\mathrm{b}}$ from $\mathrm{T}_{\mathrm{b}-\mathrm{mod}}$ (i.e., mean $\Delta \mathrm{T}_{\mathrm{b}}-\mathrm{T}_{\mathrm{b}-\mathrm{mod}}$ ) across diurnal $\mathrm{T}_{\mathrm{a}}$.

\section{Results}

\section{Rufous-cheeked Nightjar}

Due to low recapture rates, we recovered WeeDots from only two male Rufous-cheeked Nightjars (hereafter: free-ranging $\mathrm{T}_{\mathrm{b}}$ ), resulting in a total of $21,210 \mathrm{~T}_{\mathrm{b}}$ readings over 30 and 45 days. We also collected 8,869 measurements of $\mathrm{T}_{\mathrm{b}}$ over 13 days from the incubating female. Individual mean $\mathrm{T}_{\mathrm{b}}$ for the two free-ranging birds was $39.9 \pm 0.9{ }^{\circ} \mathrm{C}$ (range $\left.=36.2-43.6{ }^{\circ} \mathrm{C}, \mathrm{n}=8,394\right)$ and $39.7 \pm 1.1{ }^{\circ} \mathrm{C}\left(\right.$ range $=34.4-43.6{ }^{\circ} \mathrm{C}, \mathrm{n}=$ 12,816). Both free-ranging $T_{b}$ and incubating $T_{b}$ were distributed unimodally (Figure 1A). Mean $T_{b}, T_{b-m o d}$ and daily $H I$ were all higher in free-ranging birds compared to the incubating bird (Table 1). Daily patterns of free-ranging $T_{b}$ were characterized by transient increases in $\mathrm{T}_{\mathrm{b}}$ before sunrise and after sunset, corresponding to periods of high 
activity during twilight hours (Figure 2A). Consequently, free-ranging $\mathrm{T}_{\mathrm{b}}$ was highest during twilight periods (Table 1 ). Average daily amplitude in $\mathrm{T}_{\mathrm{b}}$ (daily $\mathrm{T}_{\mathrm{b}-\mathrm{max}}-$ daily $\mathrm{T}_{\mathrm{b}-}$ min) for the two free-ranging male Rufous-cheeked Nightjars was $5.0 \pm 0.3{ }^{\circ} \mathrm{C}$ (range $=$ $\left.2.9-8.9^{\circ} \mathrm{C}\right)$.

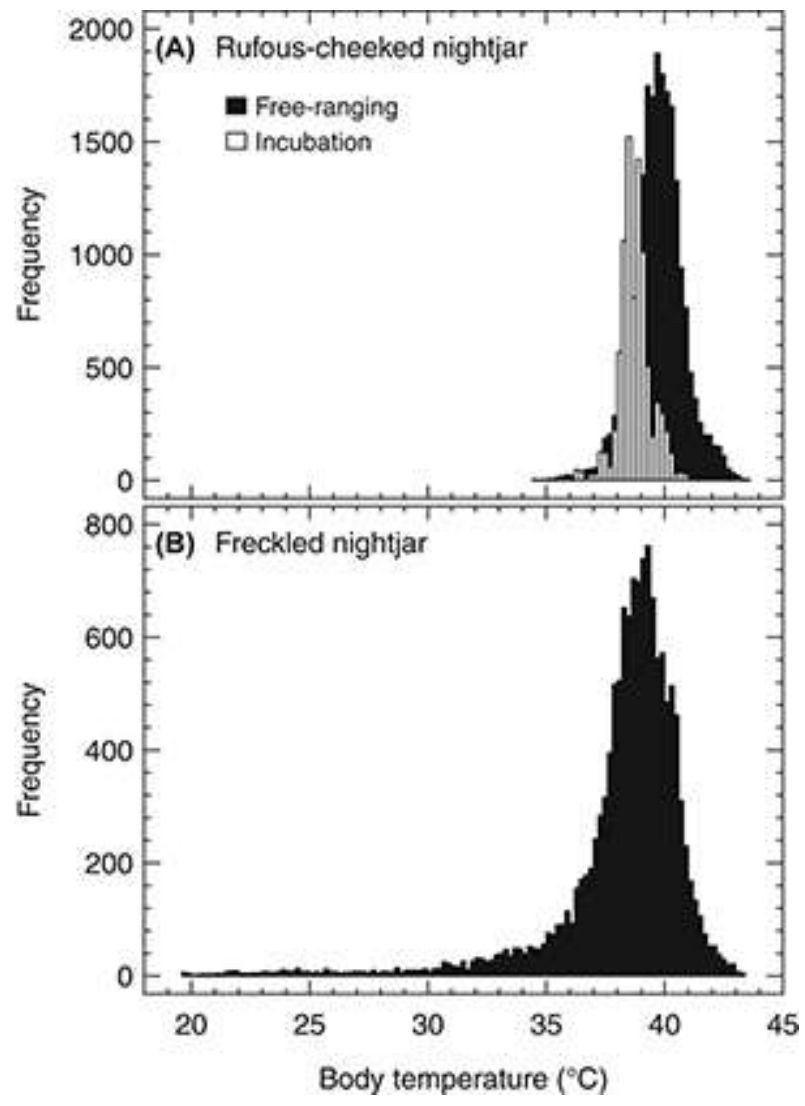

Figure 1.

Frequency distributions of summer core body temperatures $\left(T_{b}\right)$ in $(A)$ free-ranging Rufous-cheeked Nightjars (Caprimulgus rufigena; $\mathrm{N}=2$ ) from 16 January to 1 March 2014 and a single incubating Rufouscheeked Nightjar from 26 October to 11 November 2015 at Dronfield Nature Reserve, Kimberly, South Africa and, (B) free-ranging Freckled Nightjars (Caprimulgus tristigma; N = 4) from 5 December 2014 to 6 February 2015 in the Namaqualand region of South Africa. 

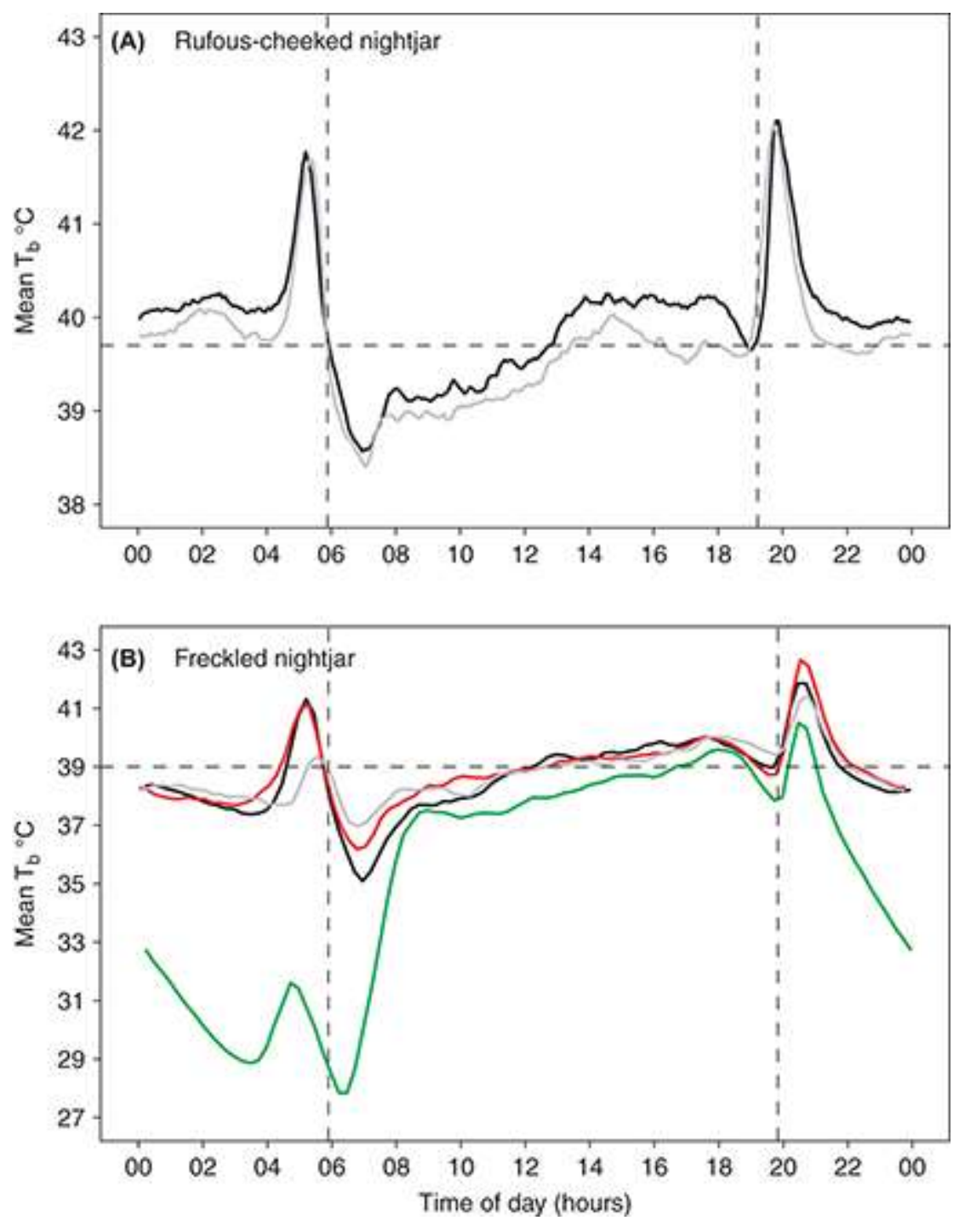

Figure 2.

Mean daily body temperature $\left(\mathrm{T}_{\mathrm{b}}\right)$ traces for $(\mathrm{A})$ free-ranging Rufous-cheeked Nightjars (Caprimulgus

rufigena; $\mathrm{N}=2$ ) from 16 January to 1 March 2014 at Dronfield Nature Reserve, Kimberley, South Africa and, (B) free-ranging Freckled Nightjars (Caprimulgus tristigma; $N=4$ ) from 5 December 2014 to 6 February 2015 in the Namaqualand region of South Africa. Each coloured line represents an individual bird. The green line is the very heterothermic Freckled Nightjar. Vertical dashed lines represent mean sunrise and sunset times for each study period. Horizontal dashed lines represent mean modal $\mathrm{T}_{\mathrm{b}}$. Note the transient increases in mean $T_{b}$ just before sunrise and right after sunset, representing periods of high activity during twilight hours. Time is shown as a 24 -h day $(0=00: 00$ hours; $22=22: 00$ hours $)$ 
Table 1. Mean \pm standard deviation values for body temperature $\left(T_{b}\right)$, modal $T_{b}\left(T_{b-m o d}\right)$, heterothermy index $(\mathrm{HI})$, maximum $\mathrm{T}_{\mathrm{b}}\left(\mathrm{T}_{\mathrm{b}-\mathrm{max}}\right)$ and $\mathrm{T}_{\mathrm{b}}$ amplitude $\left(\mathrm{T}_{\mathrm{b}-\mathrm{amp}}\right)$ from free-ranging and incubating Rufouscheeked Nightjars (Caprimulgus rufigena) and free-ranging Freckled Nightjars (Caprimulgus tristigma). Data for Rufous-cheeked Nightjar $\mathrm{T}_{\mathrm{b}}$ were recorded at 5-min intervals spanning 30 and 45 days, whereas incubating $T_{b}$ was measured at 1-min intervals over 13 days. Freckled Nightjar $T_{b}$ was measured at 15-min intervals over 21, 36, 42 and 42 days. Variable means represent averaged values across individual bird averages. Variable ranges of the raw data are given in brackets below means.

\begin{tabular}{|c|c|c|c|}
\hline \multirow[b]{2}{*}{ Variable } & \multicolumn{2}{|c|}{ Rufous-cheeked Nightjar } & \multirow[t]{2}{*}{ Freckled Nightjar $(\mathrm{N}=4)$} \\
\hline & Free-ranging $(\mathrm{N}=2)$ & Incubating $(\mathrm{N}=1)$ & \\
\hline$\overline{T_{b}}$ & $\begin{array}{l}39.8 \pm 0.2{ }^{\circ} \mathrm{C} \\
{\left[34.4-43.6^{\circ} \mathrm{C}\right]}\end{array}$ & $\begin{array}{l}38.8 \pm 0.7^{\circ} \mathrm{C} \\
{\left[36.2-41.9^{\circ} \mathrm{C}\right]}\end{array}$ & $\begin{array}{l}37.9 \pm 1.7^{\circ} \mathrm{C} \\
{\left[19.6-43.4^{\circ} \mathrm{C}\right]}\end{array}$ \\
\hline $\mathrm{T}_{\mathrm{b}-\mathrm{mod}}$ & $\begin{array}{l}39.7 \pm 0.0^{\circ} \mathrm{C} \\
{\left[39.7-39.7^{\circ} \mathrm{C}\right]}\end{array}$ & $\begin{array}{l}38.8^{\circ} \mathrm{C} \\
{[\mathrm{NA}]}\end{array}$ & $\begin{array}{l}39.0 \pm 0.3{ }^{\circ} \mathrm{C} \\
{\left[38.7-39.4{ }^{\circ} \mathrm{C}\right]}\end{array}$ \\
\hline Daily $^{\mathrm{a}} \mathrm{HI}$ & $\begin{array}{l}1.0 \pm 0.1^{\circ} \mathrm{C} \\
{\left[0.6-1.7^{\circ} \mathrm{C}\right]}\end{array}$ & $\begin{array}{l}0.7 \pm 0.2^{\circ} \mathrm{C} \\
{\left[0.4-1.1^{\circ} \mathrm{C}\right]}\end{array}$ & $\begin{array}{l}2.7 \pm 1.9{ }^{\circ} \mathrm{C} \\
{\left[0.7-10.4^{\circ} \mathrm{C}\right]}\end{array}$ \\
\hline Diurnal $^{\mathrm{b}} \mathrm{T}_{\mathrm{b}}$ & $\begin{array}{l}39.5 \pm 0.2{ }^{\circ} \mathrm{C} \\
{\left[34.4-43.2^{\circ} \mathrm{C}\right]}\end{array}$ & $\begin{array}{l}38.8 \pm 0.7^{\circ} \mathrm{C} \\
{\left[36.2-41.9^{\circ} \mathrm{C}\right]}\end{array}$ & $\begin{array}{l}38.3 \pm 0.8^{\circ} \mathrm{C} \\
{\left[19.6-42.7^{\circ} \mathrm{C}\right]}\end{array}$ \\
\hline Nocturnal $^{\mathrm{c}} \mathrm{T}_{\mathrm{b}}$ & $\begin{array}{l}40.0 \pm 0.2{ }^{\circ} \mathrm{C} \\
{\left[35.8-42.9^{\circ} \mathrm{C}\right]}\end{array}$ & $\begin{array}{l}38.9 \pm 0.3^{\circ} \mathrm{C} \\
{\left[38.3-41.9^{\circ} \mathrm{C}\right]}\end{array}$ & $\begin{array}{l}36.9 \pm 3.0^{\circ} \mathrm{C} \\
{\left[20.7-42.6^{\circ} \mathrm{C}\right]}\end{array}$ \\
\hline Twilight $^{\mathrm{d}} \mathrm{T}_{\mathrm{b}}$ & $\begin{array}{l}41.3 \pm 0.1^{\circ} \mathrm{C} \\
{\left[38.8-43.6^{\circ} \mathrm{C}\right]}\end{array}$ & $\begin{array}{l}39.7 \pm 0.5^{\circ} \mathrm{C} \\
{\left[38.8-40.9^{\circ} \mathrm{C}\right]}\end{array}$ & $\begin{array}{l}39.2 \pm 2.8^{\circ} \mathrm{C} \\
{\left[20.1-43.4^{\circ} \mathrm{C}\right]}\end{array}$ \\
\hline Diurnal $\mathrm{T}_{\mathrm{b}-\max }$ & $\begin{array}{l}41.2 \pm 0.1{ }^{\circ} \mathrm{C} \\
{\left[39.6-43.2{ }^{\circ} \mathrm{C}\right]}\end{array}$ & $\begin{array}{l}40.4 \pm 0.7^{\circ} \mathrm{C} \\
{\left[39.3-41.9^{\circ} \mathrm{C}\right]}\end{array}$ & $\begin{array}{l}40.7 \pm 0.3^{\circ} \mathrm{C} \\
{\left[38.4-42.7^{\circ} \mathrm{C}\right]}\end{array}$ \\
\hline Diurnal $T_{b-a m p}{ }^{e}$ & $\begin{array}{l}3.5 \pm 0.2^{\circ} \mathrm{C} \\
{\left[1.1-7.8^{\circ} \mathrm{C}\right]}\end{array}$ & $\begin{array}{l}2.7 \pm 0.9^{\circ} \mathrm{C} \\
{\left[1.6-4.6{ }^{\circ} \mathrm{C}\right]}\end{array}$ & $\begin{array}{l}7.3 \pm 3.8^{\circ} \mathrm{C} \\
{\left[1.8-20.2^{\circ} \mathrm{C}\right]}\end{array}$ \\
\hline Diurnal HI & $\begin{array}{l}0.9 \pm 0.1^{\circ} \mathrm{C} \\
{\left[0.3-2.0^{\circ} \mathrm{C}\right]}\end{array}$ & $\begin{array}{l}0.7 \pm 0.2^{\circ} \mathrm{C} \\
{\left[0.4-1.1^{\circ} \mathrm{C}\right]}\end{array}$ & $\begin{array}{l}2.1 \pm 1.2^{\circ} \mathrm{C} \\
{\left[0.4-7.7^{\circ} \mathrm{C}\right]}\end{array}$ \\
\hline
\end{tabular}

\footnotetext{
${ }^{\mathrm{a}}$ Defined as the period from midnight to midnight

${ }^{\mathrm{b}}$ Defined as the period between sunrise and sunset

${ }^{\mathrm{c}}$ Defined as the period between the end of nautical dusk twilight and start of nautical dawn twilight

${ }^{\mathrm{d}}$ The combined periods of civil and nautical dusk and civil and nautical dawn twilight

${ }^{\mathrm{e}}$ Calculated as $\mathrm{T}_{\mathrm{b}-\mathrm{max}}-\mathrm{T}_{\mathrm{b}-\mathrm{min}}$ during the diurnal period
} 
During the diurnal period, free-ranging Rufous-cheeked Nightjars had a higher mean $T_{b}$, greater amplitude in $T_{b}$ and higher $H I$ than the incubating bird (Table 1). The two free-ranging birds regularly decreased their $T_{b}$ after sunrise and subsequently increased $T_{b}$ with increasing $T_{a}$ throughout the day (Figure $2 A$ and Table 2). At $T_{a} \leq 30$ ${ }^{\circ} \mathrm{C}$, free-ranging Rufous-cheeked Nightjars typically maintained a mean $\mathrm{T}_{\mathrm{b}}$ below $\mathrm{T}_{\mathrm{b} \text {-mod }}$ (Figure $3 \mathrm{~A}$ ). At $\mathrm{T}_{\mathrm{a}}>33{ }^{\circ} \mathrm{C}$, diurnal $\mathrm{T}_{\mathrm{b}}$ increased sharply with $\mathrm{T}_{\mathrm{a}}$ and mean $\mathrm{T}_{\mathrm{b}}$ was consistently above $\mathrm{T}_{\mathrm{b} \text {-mod }}($ Figure $3 \mathrm{~A})$. During periods when $\mathrm{T}_{\mathrm{a}} \geq 38^{\circ} \mathrm{C}$, mean diurnal $\mathrm{T}_{\mathrm{b}}$ in free-ranging Rufous-cheeked Nightjars was $42.0 \pm 0.4{ }^{\circ} \mathrm{C}\left(\right.$ range $\left.=40.6-42.8{ }^{\circ} \mathrm{C}\right)$ and mean $\Delta \mathrm{T}_{\mathrm{b}}-\mathrm{T}_{\mathrm{b}-\bmod }$ was $2.3 \pm 0.4{ }^{\circ} \mathrm{C}$ (range $\left.=0.9-3.1{ }^{\circ} \mathrm{C}\right)$. In contrast, $\mathrm{T}_{\mathrm{b}}$ in the incubating bird was relatively stable at high $\mathrm{T}_{\mathrm{a}}$ and did not deviate far from $\mathrm{T}_{\mathrm{b} \text {-mod }}$ (Figure 3A). For example, at $\mathrm{T}_{\mathrm{a}}>33{ }^{\circ} \mathrm{C}$, mean diurnal $\mathrm{T}_{\mathrm{b}}$ in the incubating bird was $39.0 \pm 0.7{ }^{\circ} \mathrm{C}$ (range $=38.1-41.9^{\circ} \mathrm{C}$ ), only $0.2^{\circ} \mathrm{C}$ above $\mathrm{T}_{\mathrm{b}-\text { mod }}$. Consequently, diurnal $\mathrm{T}_{\mathrm{b}-\mathrm{max}}$ was higher in free-ranging birds than the incubating bird (Table 1). For free-ranging birds, diurnal $\mathrm{T}_{\mathrm{b}-\max }$ was positively and linearly related to $\mathrm{T}_{\mathrm{a}-\max }$ (Figure $4 \mathrm{~A}$ and Table 2). However, $\mathrm{T}_{\mathrm{a}-\mathrm{max}}$ did not influence diurnal $\mathrm{HI}$ in the two free-ranging birds (Figure 5A and Table 2). 


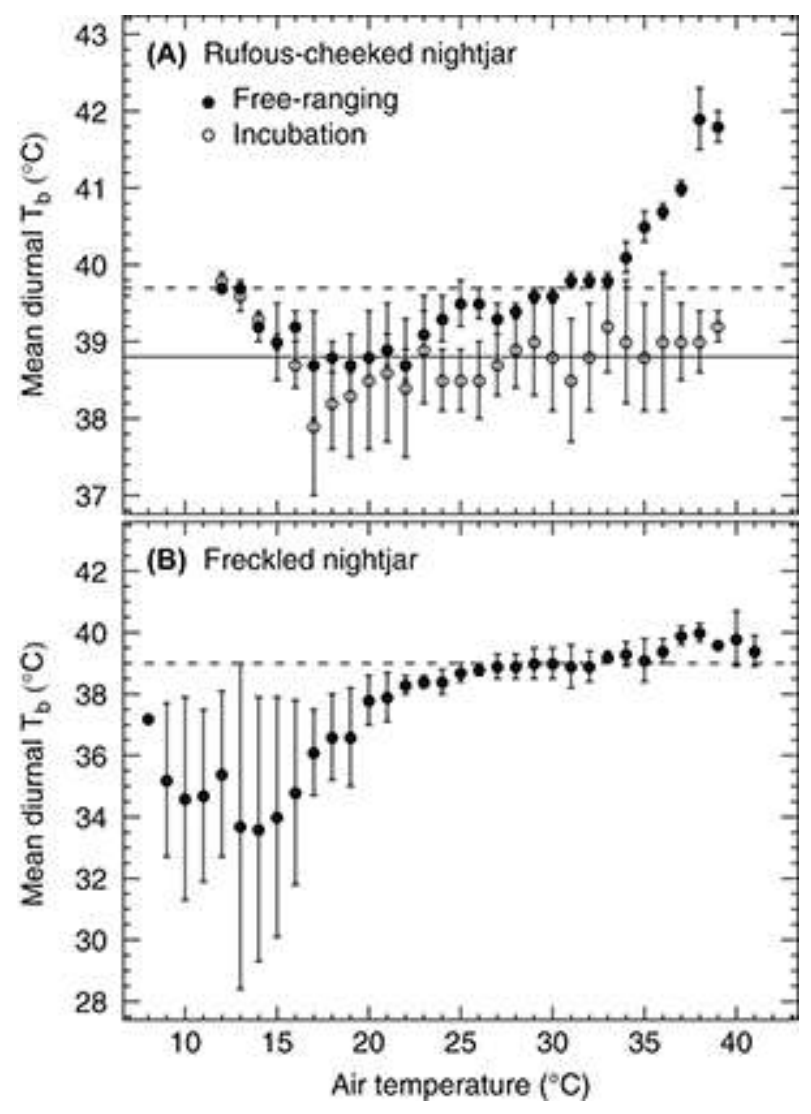

Figure 3.

Mean diurnal (i.e., sunrise to sunset) body temperature $\left(T_{b}\right)$ as a function of air temperature $\left(T_{a}\right)$ in (A) freeranging Rufous-cheeked Nightjars (Caprimulgus rufigena; $N=2$ ) from 16 January to 1 March 2014 and a single incubating Rufous-cheeked Nightjar from 26 October to 11 November 2015 at Dronfield Nature Reserve, Kimberley, South Africa and, (B) free-ranging Freckled Nightjars (Caprimulgus tristigma; N = 4) from 5 December 2014 to 6 February 2015 in the Namaqualand region of South Africa. Each data point represents mean diurnal $T_{b}$ averaged across individuals to the nearest whole $T_{a}$ (e.g., mean diurnal $T_{b}$ at $T_{a}$ $=20{ }^{\circ} \mathrm{C}$ represents the combined average $T_{b}$ of each individual birds average $T_{b}$ recorded at $19.5 \leq T_{a}<$ 20.5). Horizontal dashed lines represent the mean modal $T_{b}$ for free-ranging individuals whereas the solid horizontal line represents the modal $\mathrm{T}_{\mathrm{b}}$ for the incubating Rufous-cheeked Nightjar. Error bars represent standard deviation. 


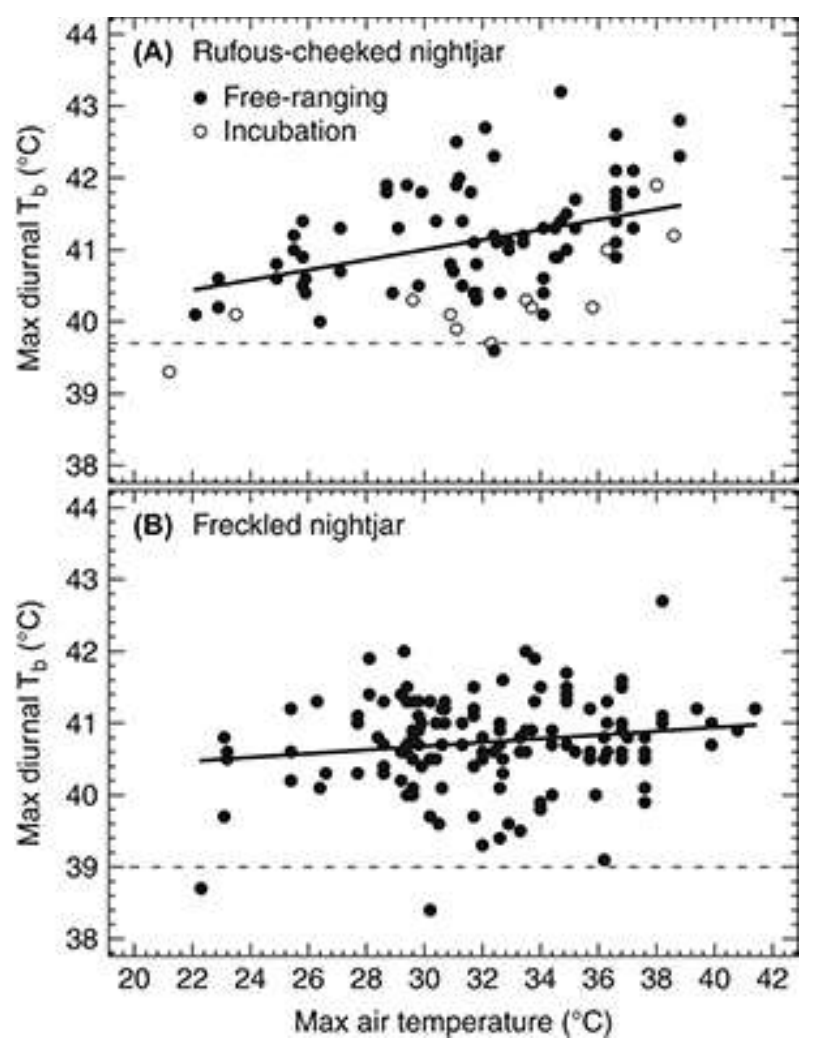

Figure 4.

Maximum diurnal (i.e., sunrise to sunset) body temperature $\left(T_{b}\right)$ as a function of maximum air temperature in (A) free-ranging Rufous-cheeked Nightjars (Caprimulgus rufigena; $\mathrm{N}=2$ ) from 16 January to 1 March 2014 and a single incubating Rufous-cheeked Nightjar from 26 October to 11 November 2015 at Dronfield Nature Reserve, Kimberley, South Africa and, (B) free-ranging Freckled Nightjars (Caprimulgus tristigma; $\mathrm{N}=4$ ) from 5 December 2014 to 6 February 2015 in the Namaqualand region of South Africa. Horizontal dashed lines represent the mean modal $\mathrm{T}_{\mathrm{b}}$ for free-ranging birds. Regression lines in both panels represent the parameter estimates from linear mixed-effects models fit to only free-ranging $T_{b}$ data. In all models bird identity was included as a random variable to account for repeated measures within individuals. 


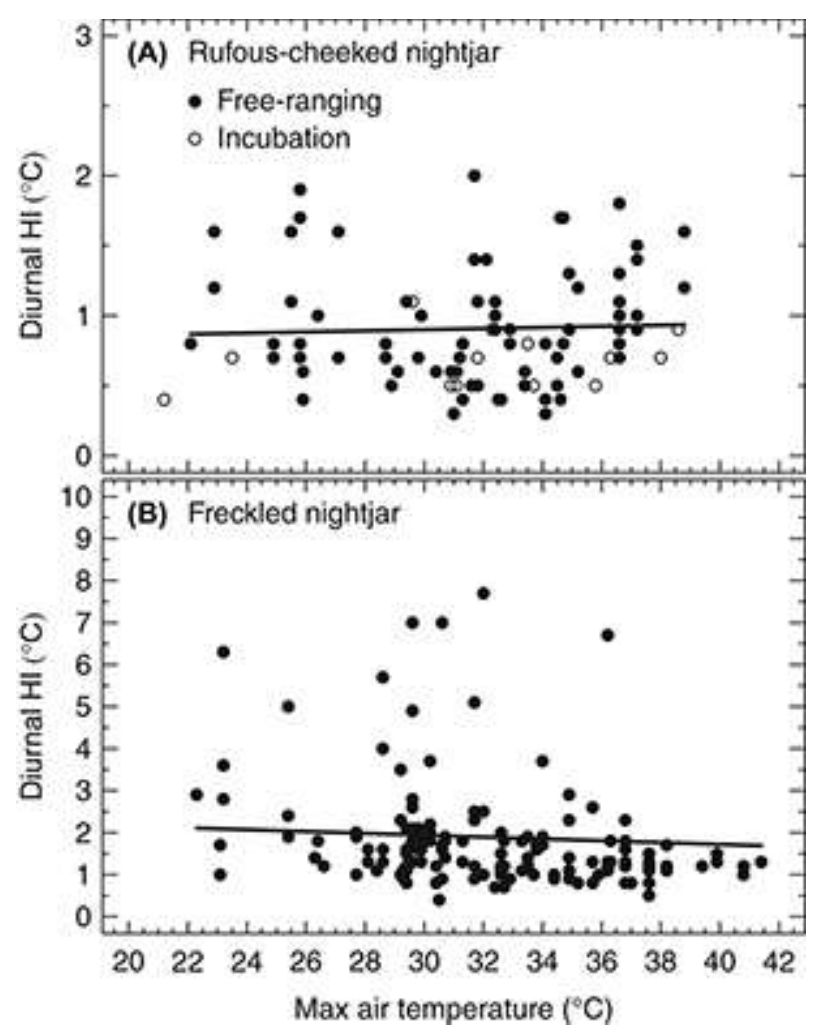

Figure 5.

Diurnal (i.e., sunrise to sunset) heterothermy index (HI) as a function of maximum air temperature in (A) free-ranging Rufous-cheeked Nightjars (Caprimulgus rufigena; N = 2) from 16 January to 1 March 2014 and a single incubating Rufous-cheeked Nightjar from 26 October to 11 November 2015 at Dronfield Nature Reserve, Kimberley, South Africa and, (B) free-ranging Freckled Nightjars (Caprimulgus tristigma; $\mathrm{N}=4$ ) from 5 December 2014 to 6 February 2015 in the Namaqualand region of South Africa. Regression lines in both panels represent the parameter estimates from linear mixed-effects models fit to only freeranging $\mathrm{T}_{\mathrm{b}}$ data. In all models bird identity was included as a random variable to account for repeated measures within individuals. 
Table 2. Parameter estimates \pm standard error $(\beta \pm \mathrm{SE})$ from linear mixed-effects models for free-ranging Rufous-cheeked Nightjars (Caprimulgus rufigena) and Freckled Nightjars (Caprimulgus tristigma). Models include body temperature as a function of air temperature $\left(\mathrm{T}_{\mathrm{b}} \sim \mathrm{T}_{\mathrm{a}}\right)$, maximum body temperature as a function of maximum air temperature $\left(\mathrm{T}_{\mathrm{b}-\max } \sim \mathrm{T}_{\mathrm{a}-\max }\right)$ and heterothermy index as a function of $\mathrm{T}_{\mathrm{a}-\max }(\mathrm{HI} \sim$ $\mathrm{T}_{\mathrm{a}-\mathrm{max}}$ ). All models represent data collected during the diurnal period, defined as the period between sunrise and sunset. Lower CI = lower $95 \%$ confidence interval. Upper CI = upper $95 \%$ confidence interval. Values in parentheses below parameter estimates represent the number of observations included in the model (e.g., for the model $\mathrm{T}_{\mathrm{b}} \sim \mathrm{T}_{\mathrm{a}}, \mathrm{n}=11,703$ diurnal $\mathrm{T}_{\mathrm{b}}$ observations from $\mathrm{N}=2$ Rufous-cheeked Nightjars). In all models bird identity was included as a random factor to account for repeated measures within individuals.

\begin{tabular}{|c|c|c|c|}
\hline Model & $\beta \pm \mathrm{SE}$ & Lower CI & Upper CI \\
\hline \multicolumn{4}{|l|}{ Rufous-cheeked Nightjar $(\mathrm{N}=2)$} \\
\hline Diurnal $\mathrm{T}_{\mathrm{b}} \sim$ diurnal $\mathrm{T}_{\mathrm{a}}$ & $\begin{array}{l}0.104 \pm 0.001 \\
(\mathrm{n}=11,703)\end{array}$ & 0.101 & 0.106 \\
\hline Diurnal $\mathrm{T}_{\mathrm{b}-\max } \sim$ diurnal $\mathrm{T}_{\mathrm{a}-\max }$ & $\begin{array}{l}0.073 \pm 0.015 \\
(n=74)\end{array}$ & 0.045 & 0.102 \\
\hline Diurnal HI $\sim$ diurnal $\mathrm{T}_{\mathrm{a}-\max }$ & $\begin{array}{l}0.004 \pm 0.012 \\
(\mathrm{n}=74)\end{array}$ & -0.016 & 0.028 \\
\hline \multicolumn{4}{|l|}{ Freckled Nightjar $(\mathrm{N}=4)$} \\
\hline Diurnal $\mathrm{T}_{\mathrm{b}} \sim$ diurnal $\mathrm{T}_{\mathrm{a}}$ & $\begin{array}{l}0.095 \pm 0.003 \\
(\mathrm{n}=7,759)\end{array}$ & 0.089 & 0.101 \\
\hline Diurnal $\mathrm{T}_{\mathrm{b}-\max } \sim$ diurnal $\mathrm{T}_{\mathrm{a}-\max }$ & $\begin{array}{l}0.026 \pm 0.013 \\
(\mathrm{n}=139)\end{array}$ & 0.0006 & 0.051 \\
\hline Diurnal HI $\sim$ diurnal $\mathrm{T}_{\mathrm{a}-\max }$ & $\begin{array}{l}-0.022 \pm 0.010 \\
(\mathrm{n}=139)\end{array}$ & -0.042 & -0.002 \\
\hline
\end{tabular}

\section{Freckled Nightjar}

We recovered iButtons from four Freckled Nightjars (three male, one female), yielding $13,353 \mathrm{~T}_{\mathrm{b}}$ readings spanning $21,36,42$ and 42 days. Freckled Nightjar $\mathrm{T}_{\mathrm{b}}$ was leftskewed with a unimodal distribution (Figure 1B). Body temperature was similar among three of the birds, with individual means of $38.7 \pm 2.0^{\circ} \mathrm{C}$ (range $=28.8-43.4{ }^{\circ} \mathrm{C}, \mathrm{n}=$ 
3,942), $38.9 \pm 2.0{ }^{\circ} \mathrm{C}\left(\right.$ range $\left.=29.1-43.4^{\circ} \mathrm{C}, \mathrm{n}=3,939\right)$ and $38.8 \pm 1.6{ }^{\circ} \mathrm{C}($ range $=31.7$

$\left.-42.6{ }^{\circ} \mathrm{C}, \mathrm{n}=3,456\right)$. One male decreased its $\mathrm{T}_{\mathrm{b}}$ below $30^{\circ} \mathrm{C}$ on 15 of 21 nights, resulting in a lower average $\mathrm{T}_{\mathrm{b}}$ of $35.4 \pm 5.1{ }^{\circ} \mathrm{C}\left(\right.$ range $\left.=19.6-41.9^{\circ} \mathrm{C}, \mathrm{n}=2,016\right)$. The exclusion of data from this bird did not alter the main results, particularly pertaining to the diurnal period (e.g., 95\% confidence intervals from mixed-effects models overlapped), and we thus opted to include this individual in our final analyses. Modal $\mathrm{T}_{\mathrm{b}}$ was similar among the four birds, only ranging by $0.7^{\circ} \mathrm{C}$ (Table 1). Body temperature showed conspicuous, transient increases before sunrise and after sunset (Figure 2B), resulting in $T_{b}$ being greatest during twilight hours followed by diurnal and nocturnal periods (Table 1). Average daily amplitude of $\mathrm{T}_{\mathrm{b}}$ was $9.0 \pm 3.6^{\circ} \mathrm{C}$ (range $=3.3-20.2$ $\left.{ }^{\circ} \mathrm{C}\right)$.

Freckled Nightjars displayed a highly variable diurnal $\mathrm{T}_{\mathrm{b}}$ with conspicuous declines after sunrise and before sunset (Figure 2B and Table 1). However, although diurnal $T_{b}$ increased with $T_{a}$ (Table 2), at high $T_{a}$ Freckled Nightjars did not allow their $T_{b}$ to rise much above $T_{b-m o d}$ (Figure 3B). For example, at $T_{a} \geq 38{ }^{\circ} \mathrm{C}$, mean diurnal $T_{b}$ was $40.0 \pm 0.5^{\circ} \mathrm{C}\left(\right.$ range $\left.=37.5-41.5^{\circ} \mathrm{C}\right)$ and mean $\Delta \mathrm{T}_{\mathrm{b}}-\mathrm{T}_{\mathrm{b}-\bmod }$ was $1.1 \pm 0.4^{\circ} \mathrm{C}($ range $\left.=-1.2-2.6^{\circ} \mathrm{C}\right)$. Consequently, $\mathrm{T}_{\mathrm{b}-\max }$ increased only marginally with $\mathrm{T}_{\mathrm{a}-\max }($ Figure $4 \mathrm{~B}$ and Table 2). On cooler days when $\mathrm{T}_{\mathrm{a}-\max } \leq 26{ }^{\circ} \mathrm{C}$, mean diurnal $\mathrm{T}_{\mathrm{b} \text {-max }}$ was $40.3 \pm 0.7{ }^{\circ} \mathrm{C}$ (range $=38.7-41.2{ }^{\circ} \mathrm{C}$ ), whereas, on warmer days when $\mathrm{T}_{\mathrm{a}-\max } \geq 36{ }^{\circ} \mathrm{C}$, mean diurnal $\mathrm{T}_{\mathrm{b}}$ max was just $40.7 \pm 0.4{ }^{\circ} \mathrm{C}\left(\right.$ range $\left.=39.1-42.7^{\circ} \mathrm{C}\right)$. Freckled Nightjars were slightly less heterothermic on days with higher $\mathrm{T}_{\mathrm{a}-\max }$ (Figure 5B and Table 2). 


\section{Discussion}

To the best of our knowledge, this is the first study focusing on diurnal $T_{b}$ patterns in free-ranging caprimulgids occupying hot, arid environments. Both species increased their mean and maximum diurnal $T_{b}$ with increasing $T_{a}$, a physiological response common among birds (Weathers 1981, Tieleman and Williams 1999). Facultative hyperthermia can reduce EWL by storing heat in the body to be dissipated later through nonevaporative pathways, increasing non-evaporative heat loss when $\mathrm{T}_{\mathrm{a}}<\mathrm{T}_{\mathrm{b}}$ and decreasing heat gain when $T_{a}>T_{b}$ (Withers 1992, Tieleman and Williams 1999). The capacity to elevate $T_{b}$ under laboratory conditions has been reported in several crepuscular and nocturnal avian species (e.g., Bartholomew et al. 1962, Lasiewski and Dawson 1964, Ligon 1968, Dawson and Fisher 1969, Ligon 1969, Weathers et al. 2001, O'Connor et al. 2017). Chaplin et al. (1984) observed an elevated diurnal $\mathrm{T}_{\mathrm{b}}$ in fasted Great Horned Owls (Bubo virginianus) at high $\mathrm{T}_{\mathrm{a}}$ and suggested that, because these owls obtain water from their diet (Duke et al. 1973), it may represent a physiological response to low preformed water intake. Thus, for nocturnal species where diurnal water intake is absent, an elevated diurnal $\mathrm{T}_{\mathrm{b}}$ could help to reduce water losses and avoid dehydration.

The average increase in diurnal $\mathrm{T}_{\mathrm{b}}$ above $\mathrm{T}_{\mathrm{b}-\mathrm{mod}}$ at $\mathrm{T}_{\mathrm{a}} \geq 38^{\circ} \mathrm{C}$ for the two freeranging Rufous-cheeked Nightjars was similar in magnitude to that of several captive diurnal species at $\mathrm{T}_{\mathrm{a}}=45^{\circ} \mathrm{C}$ (Tieleman and Williams 1999; $\left.3.3 \pm 1.28^{\circ} \mathrm{C}\right)$. In the laboratory at $\mathrm{T}_{\mathrm{a}}=38-40{ }^{\circ} \mathrm{C}\left(\mathrm{O}^{\prime} \mathrm{C}\right.$ Connor et al. 2017), this same population of Rufouscheeked Nightjars maintained a mean $\mathrm{T}_{\mathrm{b}} 1.9^{\circ} \mathrm{C}$ lower than the free-ranging mean $\mathrm{T}_{\mathrm{b}}$ of $42{ }^{\circ} \mathrm{C}$ at similar $\mathrm{T}_{\mathrm{a}}$. The dissimilarity in hyperthermia between free-ranging and captive Rufous-cheeked Nightjars at similar $\mathrm{T}_{\mathrm{a}}$ likely reflects the complexity of natural thermal 
environments compared to controlled laboratory conditions. Air temperature alone is rarely an accurate indicator of thermal stress, which instead incorporates solar radiation, wind and humidity (Porter and Gates 1969). The importance of multiple environmental variables presumably explains the overlapping hyperthermic responses of free-ranging Rufous-cheeked Nightjars with those reported by Tieleman and Williams (1999) at higher $\mathrm{T}_{\mathrm{a}}$.

At $T_{a} \geq 38{ }^{\circ} \mathrm{C}$, Freckled Nightjars did not allow their $T_{b}$ to deviate much above $T_{b}$ mod. Under laboratory conditions, the same population of Freckled Nightjars regulated $T_{b}$ at a similar level $\left(39.5{ }^{\circ} \mathrm{C}\right)$ when exposed to $\mathrm{T}_{\mathrm{a}}=38-42{ }^{\circ} \mathrm{C}$, increasing their $\mathrm{T}_{\mathrm{b}}$ to $40.7^{\circ} \mathrm{C}$ only at $\mathrm{T}_{\mathrm{a}}=52{ }^{\circ} \mathrm{C}\left(\mathrm{O}^{\prime}\right.$ Connor et al. 2017). These data suggest that Freckled Nightjars defend $T_{b}$ within a narrow range at $T_{a}>T_{b}$. Yet, Freckled Nightjars represent one of the most heterothermic caprimulgids investigated to date, with accounts of free-ranging individuals reducing skin temperature to near $10{ }^{\circ} \mathrm{C}$ (McKechnie et al. 2007, Smit et al. 2011). If, for instance, Freckled Nightjars evolved thermoregulatory strategies favouring energy conservation over heat tolerance, a thermal sensitivity tradeoff could have arisen, leading to a generalist $T_{b}$ phenotype where both their optimal $T_{b}$ and upper thermal limit has shifted downwards (Angilletta et al. 2010, Boyles et al. 2011a). In general, enzymes that perform well at low temperatures appear to function poorly at high temperatures (Hochachka and Somero 2002, Angilletta et al. 2003). We argue that the evolution of a $T_{b}$ distribution shifted downward may have selected for increased enzymatic performance at lower $T_{b}$, in turn decreasing enzymatic performance at higher $T_{b}$. It is noteworthy that the phenotypic traits of caprimulgids associated with energy conservation (e.g., low resting metabolic rate; Lane et al. 2004b) and energy acquisition (e.g., enlarged and highly 
vascularized buccal area; Cowles 1967) are probably the same traits that allow them to tolerate extremely high $\mathrm{T}_{\mathrm{a}}$ by reducing their total heat load and increasing the surface area for EWL.

We found that diurnal HI was independent of $\mathrm{T}_{\mathrm{a}-\mathrm{max}}$ in Rufous-cheeked Nightjars, reflecting quantitatively similar deviations in $\mathrm{T}_{\mathrm{b}}$ both below and above $\mathrm{T}_{\mathrm{b} \text {-mod }}$ across cooler and warmer days. In contrast, Freckled Nightjars expressed a higher diurnal HI on cooler days because of their proclivity for reducing $\mathrm{T}_{\mathrm{b}}$ below $\mathrm{T}_{\mathrm{b} \text {-mod }}$ at cooler $\mathrm{T}_{\mathrm{a}}$, as seen during morning hours. This thermoregulatory pattern of reducing $\mathrm{T}_{\mathrm{b}}$ during the morning has been observed in several crepuscular and nocturnal species (Brigham et al. 2000, Geiser 2004, Lane et al. 2004a, Smit and McKechnie 2010). The advantages of facultative reductions in $\mathrm{T}_{\mathrm{b}}$ during the morning hours are two-fold. First, a reduced $\mathrm{T}_{\mathrm{b}}$ decreases the energetic cost of maintaining an elevated $\mathrm{T}_{\mathrm{b}}$ at low $\mathrm{T}_{\mathrm{a}}$. Secondly, reducing $\mathrm{T}_{\mathrm{b}}$ around sunrise, nightjars may be able to exploit solar radiation as an exogenous energy source and passively rewarm to normothermic $\mathrm{T}_{\mathrm{b}}$, thereby reducing metabolic cost of rewarming (McKechnie and Wolf 2004).

Diurnal $\mathrm{T}_{\mathrm{b}}$ was more variable in the two free-ranging male Rufous-cheeked Nightjars compared to the one incubating female. Incubation likely places large thermoregulatory demands on adults because of the sensitivity of developing embryos to both low and high temperatures (Webb 1987, Conway and Martin 2000, DuRant et al. 2013). Consequently, incubating adults would be predicted to thermoregulate more precisely, a requirement that limits adaptive thermoregulatory strategies and increases energy and water demands (Grant 1982, Haftorn and Reinertsen 1985, Thomson et al. 1998, Lane et al. 2004a). Walsberg and Voss-Roberts (1983), for example, observed 
body temperatures $0.3-1.9^{\circ} \mathrm{C}$ lower in incubating Turtle doves (Streptopelia risoria) compared to non-incubating individuals. Although based on very small sample sizes, our data raise the possibility that, during the diurnal period when $T_{a}$ approaches or exceeds $\mathrm{T}_{\mathrm{b}}$, incubating female Rufous-cheeked Nightjars thermoregulate more precisely compared to non-incubating individuals, likely placing greater strain on their water balance.

Both Rufous-cheeked Nightjars and Freckled Nightjars had relatively labile $T_{b}$ distributed unimodally, a pattern that contrasts with the distinct circadian rhythm of $T_{b}$ typical of most birds and mammals, which results in a bimodal $\mathrm{T}_{\mathrm{b}}$ distribution (Aschoff 1982, Refinetti and Menaker 1992, Smit et al. 2013). Absolute differences between mean active-phase (twilight and nocturnal periods combined) and mean rest-phase $T_{b}$ were only 0.7 and $0.9{ }^{\circ} \mathrm{C}$ for Rufous-cheeked Nightjars and Freckled Nightjars, respectively, values substantially smaller than the $2.3{ }^{\circ} \mathrm{C}$ expected from the scaling of this trait (Prinzinger et al. 1991). Small differences between rest-phase and active-phase $T_{b}$ have been reported in several crepuscular and nocturnal species (Siegfried et al. 1975, Chaplin et al. 1984, Bech and Nicol 1999, Smit et al. 2008). Consequently, the shape of the circadian rhythm in $T_{b}$ for crepuscular and nocturnal birds does not appear to conform to the exaggerated active/rest-phase $T_{b}$ differences seen among diurnal species (e.g., Bartholomew and Dawson 1954, McKechnie and Smit 2010, Smit et al. 2013), at least not during the summer when diurnal $T_{a}$ is higher. Our understanding of the circadian rhythm of $T_{b}$ for crepuscular and nocturnal birds, especially that of highly heterothermic groups like caprimulgids, would benefit from free-ranging $T_{b}$ studies on non-migratory species 
during winter to see if diurnal $\mathrm{T}_{\mathrm{b}}$ remains elevated at colder daytime $\mathrm{T}_{\mathrm{a}}$ or exhibits a more reduced rest-phase $T_{b}$.

\section{Summary}

Free-ranging Rufous-cheeked Nightjars and Freckled Nightjars increased $\mathrm{T}_{\mathrm{b}}$ with increasing $\mathrm{T}_{\mathrm{a}}$ during the diurnal period, an adaptive thermoregulatory pattern reducing EWL. At $\mathrm{T}_{\mathrm{a}} \geq 38^{\circ} \mathrm{C}$, Rufous-cheeked Nightjars had a mean $\Delta \mathrm{T}_{\mathrm{b}}-\mathrm{T}_{\mathrm{b}-\bmod }$ of $2.3^{\circ} \mathrm{C}$, whereas Freckled Nightjars had a mean $\Delta \mathrm{T}_{\mathrm{b}}-\mathrm{T}_{\mathrm{b} \text {-mod }}$ of $1.1^{\circ} \mathrm{C}$. Given that Freckled Nightjars are one of the most heterothermic caprimulgids investigated to date, the reduced $T_{b}$ lability above $T_{b-m o d}$ raises questions regarding the co-adaptation between thermoregulation and thermosensitivity among highly heterothermic groups.

Furthermore, the observed variation in hyperthermia magnitude at similar $\mathrm{T}_{\mathrm{a}}$ underscores the importance of field-based studies for determining thermoregulatory costs at the species, and individual, level. We advocate more field-based studies measuring complex physiological responses like $T_{b}$ are needed to provide a more accurate picture of the thermoregulatory strategies used by animals under natural conditions. Freckled Nightjars displayed a marginally higher $\mathrm{HI}$ at lower $\mathrm{T}_{\mathrm{a}-\mathrm{max}}$, whereas Rufous-cheeked Nightjars expressed a similar HI across all $\mathrm{T}_{\mathrm{a}-\max }$. Finally, both species displayed an atypical circadian rhythm of $\mathrm{T}_{\mathrm{b}}$, resulting in a unimodal $\mathrm{T}_{\mathrm{b}}$ distribution that contrasts with the bimodal $\mathrm{T}_{\mathrm{b}}$ distribution common among mammals and birds.

Acknowledgements - We are very grateful to Pieter and Verencia Benade, Duncan MacFadyen and E. Oppenheimer \& Son for granting us permission to perform research 
on their properties. We also thank Dr. Hennie Venter and Dr. Joe van Heerden for performing surgeries. Cathy Bester, Ryno Kemp and Pieter Erasmus provided much needed assistance in the field. Lastly, we thank Bruce Woodroffe and Awesome Tools (Cape Town, South Africa) for providing discounted lighting equipment. Funding was provided by the DST-NRF Centre of Excellence at the Percy FitzPatrick Institute and University of Pretoria. This project was approved by the University of Pretoria Animal Ethics Committee (Projects EC068-13 and EC072-15) and complies with current South African laws. This manuscript was improved by the helpful comments of two anonymous reviewers.

\section{References}

Angilletta, M. J., Bennett, A. F., Guderley, H., Navas, C. A., Seebacher, F. and Wilson, R. S. 2006. Coadaptation: a unifying principle in evolutionary thermal biology.Physiol. Biochem. Zool. 2006 79: 282-294.

Angilletta, M. J., Cooper, B. S., Schuler, M. S. and Boyles, J. G. 2010. The evolution of thermal physiology in endotherms. - Front. Biosci. E2: 861-881.

Angilletta, M. J., Wilson, R. S., Navas, C. A. and James, R. S. 2003. Tradeoffs and the evolution of thermal reaction norms. - Trends Ecol. Evol. 18: 234-240.

Aschoff, J. 1982. The circadian rhythm of body temperature as a function of body size. In: Taylor, C. R., Johansen, R. and Bolis, L. (eds.), A companion to animal physiology. Cambridge University Press, pp. 173-188. 
Bakken, G. S. 1976. A heat transfer analysis of animals: unifying concepts and the application of metabolism chamber data to field ecology. - J. Theor. Biol. 60:337384.

Bartholomew, G. A. and Cade, T. J. 1963. The water economy of land birds. - Auk 80: $504-539$.

Bartholomew, G. A. and Dawson, W. R. 1953. Respiratory water loss in some birds of southwestern United States. - Physiol. Zool. 26: 162-166.

Bartholomew, G. A. and Dawson, W. R. 1954. Body temperature and water requirements in the Mourning Dove, Zenaidura Macroura Marginella. - Ecology 35: 181-187.

Bartholomew, G. A., Hudson, J. W. and Howell, T. R. 1962. Body temperature, oxygen consumption, evaporative water loss, and heart rate in the poor-will. - Condor 64: $117-125$.

Bates, D., Maechler, M., Bolker, B. and Walker, S. 2015. Fitting linear mixed-effects models using lme4. - Journal of Statistical Software 67: 1-48. doi:10.18637/jss.v067.i01.

Bech, C. and Nicol, S. C. 1999. Thermoregulation and ventilation in the tawny frogmouth, Podargus strigoides: a low-metabolic avian species. - Aust. J. Zool. 47: 143-153.

Bivand, R. and Lewin-Koh, N. 2016. maptools: tools for reading and handling spatial objects. $-\mathrm{R}$ package version 0.8-39. https://cran.r-project.org/package=maptools.

Boyles, J. G., Seebacher, F., Smit, B. and McKechnie, A. E. 2011a. Adaptive thermoregulation in endotherms may alter responses to climate change. - Integr. Comp. Biol. 51: 676-690. 
Boyles, J. G., Smit, B. and McKechnie, A. E. 2011b. A new comparative metric for estimating heterothermy in endotherms. - Physiol. Biochem. Zool. 84: 115-123.

Boyles, J. G., Smit, B., Sole, C. L. and McKechnie, A. E. 2012. Body temperature patterns in two syntopic elephant shrew species during winter. - Comp. Biochem. Physiol. A 161: 89-94.

Boyles, J. G., Thompson, A. B., McKechnie, A. E., Malan, E., Humphries, M. M. and Careau, V. 2013. A global heterothermic continuum in mammals. - Glob. Ecol. Biogeogr. 22: 1029-1039.

Brigham, R. M. 1992. Daily torpor in a free-ranging goatsucker, the common poorwill (Phalaenoptilus nuttallii). - Physiol. Zool. 65: 457-472.

Brigham, R. M., Körtner, G., Maddocks, T. A. and Geiser, F. 2000. Seasonal use of torpor by free-ranging Australian owlet-nightjars (Aegotheles cristatus). - Physiol. Biochem. Zool. 73: 613-620.

Brigham, R. M., McKechnie, A. E., Doucette, L. I. and Geiser, F. 2012. Heterothermy in caprimulgid birds: A review of inter- and intraspecific variation in free-ranging populations. - In: Ruf, T., Bieber, C., Arnold, W. and Millesi, E. (eds.), Living in a seasonal world. Springer Berlin Heidleberg, pp. 175-187.

Cade, T. J. and Dybas, J. A. 1962. Water economy of the budgerygah. - Auk 79: 345364.

Chaplin, S. B., Diesel, D. A. and Kasparie, J. A. 1984. Body temperature regulation in red-tailed hawks and great horned owls: responses to air temperature and food deprivation. - Condor 86: 175-181. 
Chew, R. M. 1961. Water metabolism of desert-inhabiting vertebrates. - Biol. Rev. 36: 131.

Conway, C. J. and Martin, T. E. 2000. Effects of ambient temperature on avian incubation behavior. - Behav. Ecol. 11: 178-188.

Cowles, G. S. 1967. The palate of the red-necked nightjar Caprimulgus ruficollis with a description of a new feature. - Ibis 109: 260-265.

Cowles, R. B. and Dawson, W. R. 1951. A cooling mechanism of the Texas nighthawk. Condor 53: 19-22.

Dawson, W. R. 1982. Evaporative losses of water by birds. - Comp. Biochem. Physiol. A 71: 495-509.

Dawson, W. R. and Fisher, C. D. 1969. Responses to temperature by the spotted nightjar (Eurostopodus guttatus). - Condor 71: 49-53.

Dexter, R. W. 1956. Further banding and nesting studies of the eastern nighthawk. Bird-Banding 27: 9-16.

Duke, G. E., Ciganek, J. G. and Evanson, O. A. 1973. Food consumption and energy, water, and nitrogen budgets in captive great-horned owls (Bubo virginianus). Comp. Biochem. Physiol. A 44: 283-292.

DuRant, S. E., Hopkins, W. A., Hepp, G. R. and Walters, J. R. 2013. Ecological, evolutionary, and conservation implications of incubation temperature-dependent phenotypes in birds. - Biol. Rev. 88: 499-509.

Fisher, C. D., Lindgren, E. and Dawson, W. R. 1972. Drinking patterns and behavior of Australian desert birds in relation to their ecology and abundance. - Condor 74: 111-136. 
Fletcher, Q. E., Fisher, R. J., Willis, C. K. R. and Brigham, R. M. 2004. Free-ranging common nighthawks use torpor. - J. Therm. Biol. 29: 9-14.

Geiser, F. 2004. Metabolic rate and body temperature reduction during hibernation and daily torpor. - Annu. Rev. Physiol. 66: 239-274.

Grant, G. S. 1982. Avian incubation: egg temperature, nest humidity, and behavioral thermoregulation in a hot environment. - Ornithol. Monogr. 30: 1-75.

Haftorn, S. and Reinertsen, R. E. 1985. The effect of temperature and clutch size on the energetic cost of incubation in a free-living blue tit (Parus caeruleus). - Auk 102: $470-478$.

Hochachka, P. W. and Somero, G. N. 2002. Biochemical adaptation. - Oxford University Press.

Howell, T. R. 1959. A field study of temperature regulation in young least terns and common nighthawks. - Wilson Bull. 71: 19-32.

Ingels, J., Ribot, J. and de Jong, B. H. J. 1984. Vulnerability of eggs and young of the blackish nightjar (Caprimulgus nigrescens) in Suriname. - Auk 101: 388-391.

Jetz, W., Steffen, J. and Linsenmair, K. E. 2003. Effects of light and prey availability on nocturnal, lunar and seasonal activity of tropical nightjars. - Oikos 103: 627-639.

Koller, M. 2016. robustlmm: robust linear mixed effects models. - R package version 1.8. https://cran.r-project.org/package=robustlmm.

Lane, J. E., Brigham, R. M. and Swanson, D. L. 2004a. Daily torpor in free-ranging whip-poor-wills (Caprimulgus vociferus). - Physiol. Biochem. Zool. 77: 297-304.

Lane, J. E., Swanson, D. L., Brigham, R. M. and McKechnie, A. E. 2004b. Physiological responses to temperature by whip-poor-wills: more evidence for the evolution of 
low metabolic rates in caprimulgiformes. - Condor 106: 921-925.

Lasiewski, R. C. and Dawson, W. R. 1964. Physiological responses to temperature in the common nighthawk. - Condor 66: 477-490.

Ligon, J. D. 1968. The biology of the elf owl, Micrathene whitneyi. - Miscellaneous Publications of Museum of Zoology, University of Michigan 136: 1-70.

Ligon, J. D. 1969. Some aspects of temperature relations in small owls. - Auk 86: 458472.

McKechnie, A. E. and Lovegrove, B. G. 2002. Avian facultative hypothermic responses: a review. - Condor 104: 705-724.

McKechnie, A. E. and Smit, B. 2010. Thermoregulation under seminatural conditions in two species of African barbets (Piciformes: Lybiidae). - Ostrich 81: 97-102.

McKechnie, A. E. and Wolf, B. O. 2004. Solar radiation and the energetic cost of rewarming from torpor. - In: Barnes, B. M. and Carey, H. V. (eds.), Life in the cold: evolution, mechanisms, adaptation, and application. Twelfth International Hibernation Symposium. Biological Papers of the University of Alaska, number 27. Institute of Arctic Biology, University of Alaska Fairbanks, Alaska, USA, pp. 359366.

McKechnie, A. E. and Wolf, B. O. 2010. Climate change increases the likelihood of catastrophic avian mortality events during extreme heat waves. - Biol. Lett. 6: 253256.

McKechnie, A. E., Ashdown, R. A. M., Christian, M. B. and Brigham, R. M. 2007. Torpor in an African caprimulgid, the freckled nightjar Caprimulgus tristigma. - J. Avian Biol. 38: 261-266. 
Mills, A. M. 1986. The influence of moonlight on the behavior of goatsuckers (Caprimulgidae). - Auk 103: 370-378.

Mills, A. M. 2008. Latitudinal gradients of biologically useful semi-darkness. Ecography 31: 578-582.

O’Connor, R. S., Wolf, B. O., Brigham, R. M. and McKechnie, A. E. 2017. Avian thermoregulation in the heat: efficient evaporative cooling in two southern African nightjars. - J. Comp. Physiol. B 187: 477-491.

Pinheiro, J., Bates, D., DebRoy, S., Sarkar, D. and R Core Team. 2016. _nlme: linear and nonlinear mixed effects models_. - R package version 3.1-128. http://cran.rproject.org/package=nlme.

Porter, W. P. and Gates, D. M. 1969. Thermodynamic equilibria of animals with environment. - Ecol. Monogr. 39: 227-244.

Prinzinger, R., Preßmar A. and Schleucher, E. 1991. Body temperature in birds. - Comp. Biochem. Physiol. A 99: 499-506.

R Core Team 2016. R: a language and environment for statistical computing. - R Foundation for Statistical Computing. Vienna, Austria. https://www.r-project.org/. Refinetti, R. and Menaker, M. 1992. The circadian rhythm of body temperature. Physiol. Behav. 51: 613-637.

Robinson, D. E., Campbell, G. S. and King, J. R. 1976. An evaluation of heat exchange in small birds. J. Comp. Physiol. B 105:153-166.

Ruf, T. and Geiser, F. 2015. Daily torpor and hibernation in birds and mammals. - Biol. Rev. 90: 891-926.

Scholander, P. F., Hock, R., Walters, V. and Irving, L. 1950. Adaptation to cold in arctic 
and tropical mammals and birds in relation to body temperature, insulation, and basal metabolic rate. - Biol. Bull. 99: 259-271.

Siegfried, W. R., Abraham, R. L. and Kuechle, V. B. 1975. Daily temperature cycles in barred, great-horned and snowy owls. - Condor 77: 502-506.

Smit, B. and McKechnie, A. E. 2010. Do owls use torpor? Winter thermoregulation in free- ranging pearl- spotted owlets and African scops- owls. - Physiol. Biochem. Zool. 83: 149-156.

Smit, B., Boyles, J. G., Brigham, R. M. and McKechnie, A. E. 2011. Torpor in dark times: patterns of heterothermy are associated with the lunar cycle in a nocturnal bird. - J. Biol. Rhythms 26: 241-248.

Smit, B., Brown, M. and Downs, C. T. 2008. Thermoregulatory responses in seasonally acclimatized captive southern white-faced scops-owls. - J. Therm. Biol. 33: 76-86.

Smit, B., Harding, C. T., Hockey, P. A. R. and McKechnie, A. E. 2013. Adaptive thermoregulation during summer in two populations of an arid-zone passerine. Ecology 94: 1142-1154.

Steyn, P. 1971. Notes on the breeding biology of the freckled nightjar. - Ostrich 42: 179188.

Swisher, O. D. 1978. Poor-wills nesting in southwestern Oregon. - North American Bird Bander 3: 152-155.

Thomson, D. L., Monaghan, P. and Furness, R. W. 1998. The demands of incubation and avian clutch size. - Biol. Rev. 73: 293-304.

Tieleman, B. I. and Williams, J. B. 1999. The role of hyperthermia in the water economy of desert birds. - Physiol. Biochem. Zool. 72: 87-100. 
Walsberg, G. E. and Voss-Roberts, K. A. 1983. Incubation in desert-nesting doves: mechanisms for egg cooling. - Physiol. Zool. 56: 88-93.

Weathers, W. W. 1981. Physiological thermoregulation in heat-stressed birds: consequences of body size. - Physiol. Zool. 54: 345-361.

Weathers, W. W., Hodum, P. J. and Blakesley, J. A. 2001. Thermal ecology and ecological energetics of California spotted owls. - Condor 103: 678-690.

Webb, D. R. 1987. Thermal tolerance of avian embryos: a review. - Condor 89: 874-898.

Weller, M. W. 1958. Observations on the incubation behavior of a common nighthawk. Auk 75: 48-59.

Whitfield, M. C., Smit, B., McKechnie, A. E. and Wolf, B. O. 2015. Avian thermoregulation in the heat: scaling of heat tolerance and evaporative cooling capacity in three southern African arid-zone passerines. - J. Exp. Biol. 218: 17051714.

Willoughby, E. J. and Cade, T. J. 1967. Drinking habits of birds in the central Namib Desert of south west Africa. - Scientific Papers of the Namib Desert Research Station 31: 1-35.

Withers, P. C. 1992. Comparative animal physiology. - Saunders College Publishing.

Wolf, B. O. 2000. Global warming and avian occupancy of hot deserts; a physiological and behavioral perspective. - Rev. Chil. Hist. Nat. 73: 395-400.

Zuur, A. F., Ieno, E. N., Walker, N. J., Saveliev, A. A. and Smith, G. M. 2009. Mixed effects models and extensions in ecology with R. - Springer. 